\title{
Response to Gunst and Casaer on the letter to the editor "Is the protein intake saturated at doses recommended by the feeding guidelines for critically ill patients?"
}

\author{
Arthur Raymond Hubert van Zanten * ${ }^{*}$ and on behalf of the study group
}

See related research by Gunst and Casaer, https://ccforum.biomedcentral.com/articles/10.1186/s13054-018-2149-z

We thank Drs Gunst and Casaer for their interest in our study showing that a very high intact-protein enteral formula (VHPF) can successfully provide protein intakes according to nutritional recommendations in overweight critically ill patients [1]. The authors speculate, by roughly estimating and referring to post hoc data from the EPaNIC-trial using parenteral nutrition, that two-thirds of the additional protein provided could be wasted in urea, potentially inducing harm. We were asked to calculate the cumulative amount of nitrogen retained [2].

Our study investigated protein and energy intake, gastrointestinal tolerance, and safety of a new VHPF $(8 \mathrm{~g} / 100 \mathrm{kcal})$ compared with a standard high intact-protein $(5 \mathrm{~g} / 100 \mathrm{kcal})$ enteral formula (SHPF). As an exploratory parameter, urinary nitrogen excretion measured on day 5 was $24 \mathrm{~g} /$ day in the $\mathrm{VHPH}$ group and $18 \mathrm{~g} /$ day in the SHPF group. Cumulative calculations, as suggested by Gunst, cannot be performed based on single 24-h measurements. Moreover, individual urinary nitrogen measurements could not be adequately matched with nutritional intake. Consequently, calculations based on extrapolations and assumptions will produce unreliable conclusions.

Previous studies showed that higher protein intake seems to result in improved nitrogen balance despite higher urinary urea excretion [3]. The suggested harmful effect on renal function was not demonstrated in our study.
While high protein intake is essential, the recent Protinvent study [4] suggests a slower build-up in the first ICU days should be considered. Furthermore, for most ICU patients, initial conservative energy provision has been recommended to reduce the risks of gastrointestinal intolerance and refeeding syndrome, and possibly to prevent autophagy deficiency [5].

Consequently, increasing both energy and protein in parallel may be most favorable to meet nutritional needs throughout the various phases of ICU stay. Figure 1 depicts how these nutritional targets can be achieved with a single VHPF.

In conclusion, our study showed high protein intakes according to guidelines did not result in adverse renal consequences. We suggest that a very high protein product is required to achieve an optimal energy-protein balance using a personalized build-up feeding strategy, without excessive or harmful high protein intakes or overfeeding risk.

Further investigation of protein dosing and timing on nitrogen retention and clinical outcomes is warranted. Definitive conclusions about high protein intake during critical illness can be made only based on confirmatory research, including well-designed tracer studies.

As an example, a feeding regimen with a gradual increase in calories towards target during the first week and an increase in protein intake over time 


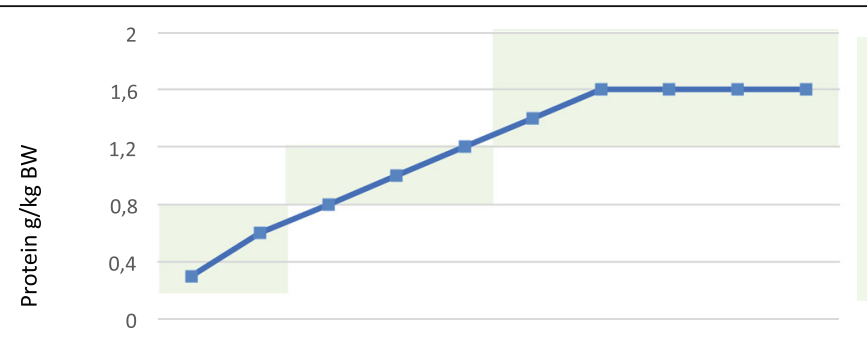

Target ranges based on PROTINVENT study and nutritional guidelines

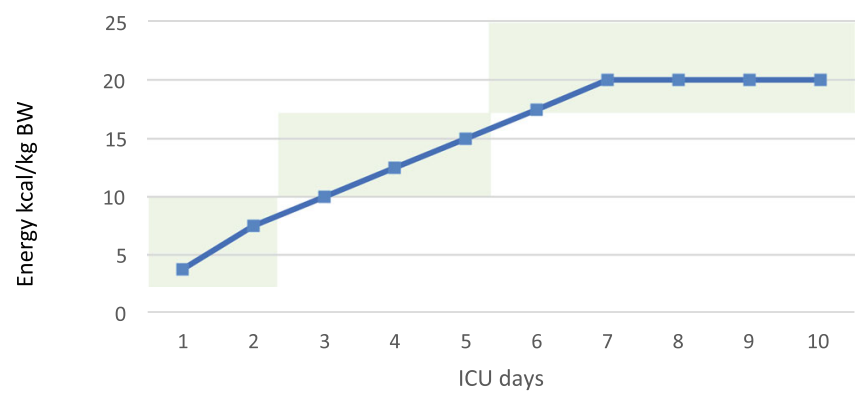

Target ranges based on nutritional guidelines

Target ranges based on -Hypocaloric feeding -Early trophic feeding

\begin{tabular}{|c|c|c|c|c|c|c|c|c|c|c|}
\hline 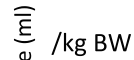 & 3 & 6 & 8 & 10 & 12 & 14 & 16 & 16 & 16 & 16 \\
\hline $\begin{array}{l}\text { E } 75 \mathrm{~kg} \\
\bar{O} \\
\text { p patient }\end{array}$ & 225 & 450 & 600 & 750 & 900 & 1050 & 1200 & 1200 & 1200 & 1200 \\
\hline
\end{tabular}

Feeding protocol

Fig. 1 Example of simple-personalized feeding regimen (Protinvent-based protocol) with very high protein enteral nutrition ( $8 \mathrm{~g}$ protein/100 kcal, $1.25 \mathrm{kcal} / \mathrm{ml}$ ) for a parallel increase in energy and protein intake in line with recommended intakes. BW body weight

was found to be associated with the lowest mortality in the Protinvent study [3]. Intake (days $1-2, \quad<0.8 \mathrm{~g} / \mathrm{kg} /$ day; days $3-5, \quad 0.8-1.2 \mathrm{~g} / \mathrm{kg} /$ day; from day $5>1.2 \mathrm{~g} / \mathrm{kg} /$ day) is depicted as milliliters per kilogram body weight per day and milliliters per day for a 75-kg patient.

\section{Acknowledgements}

The original study group comprised the following investigators: Laurent Petit, Jan de Waele, Hans Kieft, Janneke de Wilde, Peter van Horssen, Marianne Klebach, and Zandrie Hofman. Arthur R.H. van Zanten was the principal investigator.

\section{Funding}

None.

\section{Availability of data and materials}

Not applicable.

\section{Authors' contributions}

ARHZ drafted the final manuscript and is accountable for all aspects of the work. All the investigators of the study team approved the final version of the manuscript.

Ethics approval and consent to participate Not applicable.

\section{Competing interests}

Dr. van Zanten reported that he received honoraria for advisory board meetings, lectures, and travel expenses from Abbott, Baxter, BBraun, Cardinal Health, Danone-Nutricia, Fresenius Kabi, Lyric, and Nestlé-Novartis. Inclusion fees for patients in clinical trials were paid to the local ICU research foundation.

\section{Publisher's Note}

Springer Nature remains neutral with regard to jurisdictional claims in published maps and institutional affiliations.

Received: 29 August 2018 Accepted: 12 September 2018 Published online: 04 December 2018

\section{References}

1. van Zanten ARH, Petit L, De Waele J, Kieft H, de Wilde J, van Horssen P, Klebach M, Hofman Z. Very high intact-protein formula successfully provides protein intake according to nutritional recommendations in overweight critically ill patients: a double-blind randomized trial. Crit Care. 2018;22(1):156.

2. Gunst J, Casaer MP. Is the protein intake saturated at doses recommended by the feeding guidelines for critically ill patients? letter to the editor. Crit Care. 2018; 22(1):230.

3. Sundstrom Rehal M, Liebau F, Tjader I, Norberg A, Rooyackers O, Wernerman J. A supplemental intravenous amino acid infusion sustains a positive protein balance for 24 hours in critically ill patients. Crit Care. 2017;21 (1):298.

4. Koekkoek WACK, van Setten CHC, Olthof LE, Kars JCNH, van Zanten ARH. Timing of PROTein INtake and clinical outcomes of adult critically ill patients on prolonged mechanical VENTilation: The PROTINVENT retrospective study. Clin Nutr. 2018

5. Koekkoek K, van Zanten ARH. Nutrition in the ICU: new trends versus oldfashioned standard enteral feeding? Curr Opin Anaesthesiol. 2018;31(2):136-43.

\section{Consent for publication}

Not applicable. 